\title{
NATIONAL GUIDELINES FOR THE MANAGEMENT OF DIABETES MELLITUS: A NURSING PERSPECTIVE
}

\section{COLEEN A O'BRIEN}

M Cur

Registered Nurse, Day Clinic/Gastroenterology Unit, Greenacres Hospital, Port Elizabeth

\section{DALENA VAN ROOYEN}

DCur

Professor, Nursing Science, Nelson Mandela Metropolitan University, Port Elizabeth

Corresponding author: dalena.vanrooyen@nmmu.ac.za

\author{
SHEREE CARLSON \\ DCur \\ Senior Lecturer, Nursing Science, Nelson Mandela Metropolitan University, Port Elizabeth
}

Keywords: diabetes mellitus; national guidelines; primary health care; registered nurse; outpatient departments

\begin{abstract}
Since 1994, the emphasis in the provision of health services in South Africa has shifted from hospital-based care to a community-based comprehensive primary health care system, especially important in the management of chronic diseases, such as Diabetes Mellitus (DM). The incidence of DM is rapidly increasing on a global basis according to the World Health Organization, resulting in the development of evidence-based guidelines for control and management of diabetes mellitus in many countries around the world. The aim of these guidelines is to provide optimal care for patients as efficiently and cost-effectively as possible, facilitate the early detection of the condition and to provide a framework for patient education, essential for self-management and self-monitoring of the condition. Registered nurses play an extremely important role in the management of patients with DM. In this study, the views of registered nurses on the national guidelines for the control and management of DM (Type 2) were explored and described and methods of facilitating the implementation of the national guidelines in practice were identified. A qualitative, exploratory, descriptive and contextual approach was used. Registered nurses who participated in this study had definite positive views on the guidelines, were satisfied with the content of the guidelines and viewed them as an effective contribution to the management of DM, if implemented correctly. However, the participants identified several factors hindering the effective implementation of the guidelines. Recommendations to assist registered nurses in the implementation and utilisation of the national guidelines for the management of DM were constructed.
\end{abstract}

\section{OPSOMMING}

Vanaf 1994 het die klem ten opsigte van die voorsiening van gesondheidsdienste in Suid-Afrika verskuif van hospitaalgebaseerde gesondheidsorg na 'n gemeenskapsgebaseerde omvattende primêre gesondheidsorgsisteem, veral wat die hantering van chroniese siektes soos Diabetes Mellitus (DM) betref. Die voorkoms van DM neem volgens die Wêreld Gesondheid Organisasie wêreldwyd vinnig toe, gevolglik word bewysgebaseerde riglyne vir die beheer en hantering van DM in baie lande ontwikkel. Die doel van hierdie riglyne is om optimale versorging aan pasiënte so koste-effektief moontlik te voorsien, om die vroeë opsporing van DM (Tipe 2) te fasiliteer en om 'n raamwerk vir pasiëntvoorligting daar te stel wat noodsaaklik is vir selfhantering en selfmonitering van die gesondheidsprobleem. Geregistreerde verpleegkundiges speel ' $n$ uiters belangrike rol in die hantering van pasiënte met DM. Die oortuigings van geregistreerde verpleegkundiges ten opsigte van die nasionale riglyne vir die beheer en hantering van DM (tipe 2) is in hierdie studie ondersoek en beskryf en metodes om die implementering van die nasionale riglyne in die praktyk te fasiliteer, is geïdentifiseer. Geregistreerde verpleegkundiges wat aan hierdie 
studie deelgeneem het, het definitiewe positiewe menings ten opsigte van die nasionale riglyne. Hulle is tevrede met die inhoud van die riglyne en beskou dit as ' $n$ effektiewe bydrae tot die hantering van DM, indien dit korrek geïmplementeer word. Die deelnemers het egter verskeie faktore geïdentifiseer wat die effektiewe implementering van die riglyne belemmer. Aanbevelings is voorgestel om die geregistreerde verpleegkundiges te ondersteun in die implementering en gebruik van die nasionale riglyne.

\section{INTRODUCTION AND PROBLEM STATE- MENT}

In recent years in South Africa, as a result of financial and social issues, the emphasis in health care services has shifted from a hospital-based system to community-based comprehensive primary health care (Muller, 1998:110). The primary health care clinic system is designed to prevent an inundation of patients in the state-funded hospitals, as well as the provision of health care services close to the place of residence of as many people as possible. The creation of community-based health care facilities has far-reaching implications regarding the provision of efficient and effective health care services in this country. The communitybased health care policy also emphasises the value of the role of the primary health care services in both the treatment and prevention of chronic diseases, such as Diabetes Mellitus (DM-Type 2).

DM is a group of metabolic conditions characterised by raised blood glucose levels (Smeltzer \& Bare, 2004:1150). It may be caused by inadequate insulin secretion, reduced insulin action, or both, depending on the type of DM. Type 1 diabetes was formerly known as insulin-dependant diabetes while Type 2 diabetes was known as non-insulin dependant diabetes (Smeltzer \& Bare, 2004:1150). This study focussed on the National Guidelines for the management of Type 2 diabetes.

Registered nurses have an extremely important role to play in the treatment of patients with DM. Studies reviewed by Renders, Valk, Griffin, Wagner, Van and Assendelft (2001:1823) showed that a greater involvement of nurses in diabetes management reported positive effects on the outcomes of the management of the condition. The brunt of the health service provision rests on the registered nurses who form more than $60 \%$ of health care workers in South Africa with a nurse:population ratio of 43:10 000 (Muller, 1998:122). At present, particularly in the public health care ser- vices, the main burden of the large number of patients being seen at hospitals and clinics is being borne by nursing staff. Many of these nurses are in a position where they do not have the basic facilities, such as medical equipment and drugs, to perform an adequate service to their patients (Bantubani, Puoane \& Levitt, 2003:37). Patients often feel more at ease when speaking to nurses than to other health professionals about problems and/or symptoms they experience and, thus, a nurse who is adequately trained and alert should be able to identify patients at risk who require further investigation. Patients are often not aware of the implications of DM and the importance of compliance with the treatment regime. The patient must be empowered to take a more active role and greater responsibility for their own treatment (Department of Health, 2004:1). This can only be done with adequate education and training of patients with DM by, inter alia, knowledgeable and competent nursing staff. During discussions with registered nurses working at public health clinics, it often appeared as if they were either unaware or unsure of the content of the national guidelines.

$\mathrm{DM}$ is one of the chronic lifestyle diseases affecting a large sector of the population worldwide. Figures published by the World Health Organization estimated that 150 million people have DM globally and that this figure would double by the year 2025 (Rotchford \& Rotchford, 2002:60). Management strategies for DM in first world countries may vary largely from management strategies applied in third world areas because of both economic and manpower factors. However, there are many areas in other countries, including the United States of America (USA), where factors such as poverty and unemployment affect the local population, making access to health resources difficult and expensive (Safran, Mukhtar \& Murphy, 2003:58). The use of international guidelines for the provision of adequate health services for diabetic patients adapted to the conditions prevailing in developing countries can be a significant factor in reducing health-care costs in both the private and public sector while delivering safe, cost- 
effective and comprehensive health care to the patients.

This disease was considered a rarity in sub-Saharan Africa, but is now recognised as a major health problem with surveys undertaken in South Africa indicating that the prevalence of DM is estimated at approximately $8 \%$ in urbanised black populations (Rotchford \& Rotchford, 2002:60). A national programme for the treatment of Type $2 \mathrm{DM}$ at primary health care level was introduced with the development of the national guidelines for the management of DM (Type 2) in 1997, because of the importance of the condition and the potential for costly complications (Leuner, 2000:410).

The Province of the Eastern Cape is no exception to the trend of rising incidence in DM. The Nelson Mandela Metropole, situated in the Western Region of the Eastern Cape Province, has a wide range of social and demographic groupings with a very high rate of unemployment in some sections. Estimates indicate that the Nelson Mandela Metropole has an unemployment rate of $40 \%$, rising to $50-60 \%$ in the urban areas (Draft Environmental Impact Report, 2002:48). Poverty is closely linked to the development of DM, as it is difficult for poverty-stricken people to have an adequate diet or to obtain medical services.

DM is a condition requiring a high incidence of selfmanagement along with intensive medical care to reduce the incidence of complications (American Diabetes Association Position Statement, 2002:214). Glycaemic control is of paramount importance in preventing complications such as cardiovascular disease, retinopathy, neuropathy and nephropathy (American Diabetes Association Position Statement, 2002:215). The incidence and severity of both acute and chronic complications can be reduced by quality health care. In South Africa, national guidelines for the management of DM and related conditions, designed by the Department of Health to facilitate the implementation of research findings, are valuable tools for effective treatment and prevention of complications (Department of Health, 2004:1).

The management of DM, however, goes beyond simply maintaining glycaemic control, as it affects the lifestyle of the patient drastically. Diet is the most important control measure, preventing complications and improving the condition of the patient. Diet is also an important factor in the management of various co-morbid conditions, such as hypertension and renal failure, accompanying this disease. However, poverty prevents patients from enjoying a balanced diet, which would help prevent the occurrence of many of the complications occurring with this condition. Poverty also may influence access to information sources, which could assist patients in maintaining adequate glycaemic control (Wilkinson, Gouws, Sach \& Karim, 2001:665).

Unfortunately, patients often only present with DM when complications have occurred, as the development of DM is so insidious (Larme \& Pugh, 2001:1730). Early detection and correct treatment of DM could prevent the occurrence of complications, saving the state thousands of rands which could be better utilised in the prevention of complications (Larme \& Pugh, 2001:1730).

The researchers recognise the value of evidence-based guidelines in optimal cost-effective management of DM and the prevention of related complications and wanted to answer the following research questions in this study:

- What are the views of registered nurses on using and implementing the national guidelines for the management of DM?

- What recommendations can be made to assist them in this process?

\section{RESEARCH OBJECTIVES}

In this study, the following objectives were identified:

- The exploration and description of the views of registered nurses on the national guidelines for the management of DM.

- Compilation of recommendations for registered nurses to ensure optimal utilisation and implementation of the available guidelines to enhance diabetic care.

\section{RESEARCH DESIGN}

This research study was a qualitative, explorative, descriptive study reflecting the views of the registered nurse on the national guidelines for the management of DM. The views of the registered nurses were explored during semi-structured qualitative interviews conducted on an individual basis (Holloway \& Wheeler, 2002:8). 


\section{RESEARCH METHOD}

This study was conducted in two phases. Phase One covered the stages of sampling, data collection, data analysis and literature control. During Phase Two, a number of recommendations were made which will aid the registered nurse in the implementation of the guidelines for the management of DM.

\section{Population and Sampling}

Purposive sampling was used to identify the participants in the study as this is a type of non-probability sampling method in which the researcher consciously selects subjects for the study on the basis of personal judgement about which ones (participants) will be most representative or productive (Burns \& Grove, 2003:255).

As a specific group was identified, namely registered nurses working in primary health care clinics at statefunded hospitals in the Nelson Mandela Metropole, a homogeneous sampling method was considered to be most suitable (Holloway \& Wheeler, 2002:123). The selection criteria included registered nurses who:

- had been working in a diabetic clinic linked to a hospital for at least one year;

- were willing to peruse the guidelines provided and give feedback;

- were willing to participate in a semi-structured interview;

- were representative of different culture groups; and

- speak either English or Afrikaans.

At each of the three hospitals included in the study, there is one specialist diabetic nurse. The other participants had no special training in diabetes but were guided by and had received in-service training from the specialist diabetic nurses. They had all worked in the diabetic clinics for more than one year and were representative of the various cultural groups served by the hospitals. The staffing at the hospitals surveyed reflects the cultural mix of the Eastern Cape.

The participants in this study deal with patients who attend local provincial hospitals. Although the hospitals were previously termed white or non-white by the previous government, this does not apply now as the patients seen at all the clinics are representative of all the local cultural groups. These patients are often (but not always) of a low socio-economic group, often without a high standard of education due to the circumstances which they experienced in the past. Because of their social circumstances, they find it difficult to adhere to the treatment guidelines due to lack of information resources, difficulty in obtaining adequate health care as well as due to poverty levels which prevent them from adhering to a balanced diet. It is also often difficult for the patients to understand the importance of glycaemic control and the intricacies of managing their condition. The role of the registered nurse in treating and educating these patients is of paramount importance.

\section{Data Collection}

Semi-structured interviews on an individual basis, with an interview schedule were used in gathering data for this study as this method provides a focus on the areas being investigated while allowing the participants to give their own perspectives and experiences freely (Holloway \& Wheeler, 2002:82). The interview schedule ensures that there is some control and that all relevant and required aspects of the research are dealt with (Holloway \& Wheeler, 2002:82). The questions were based on eliciting information concerning the following:

- Tell me about your views of the national guidelines for the management of DM.

- Tell me about the implementation and utilisation of these guidelines.

- Have you any recommendations about these guidelines?

- How can registered nurses ensure that these guidelines are optimally implemented in order to enhance diabetic care?

Data gathering continued until the stage was reached when no new insights were obtained which meant that data saturation was achieved (Holloway \& Wheeler, 2002:85). Field notes provided a detailed record of all interviews, enhancing the richness of the data gathered. Interviews were recorded using an audiotape and were transcribed verbatim, producing an accurate representation of the interview proceedings.

\section{Data Analysis}

Themes recurring in the data were identified using Tesch's method of data analysis. This method organi- 
ses the data, creating a structure, which can then be analysed (Tesch in Creswell, 2003:192). Coding was undertaken by both an independent coder, as well as the researcher, to ensure trustworthiness.

A literature control was conducted, comparing the data with existing research. In qualitative research this is done after the data has been gathered so that the information in the available literature does not influence the questions asked by the researcher during the interviews, allowing the findings to be placed in the context of general scientific knowledge without any undue influence of that knowledge (Holloway \& Wheeler, 2002:30).

\section{Trustworthiness}

Qualitative research has its own constructs or criteria for evaluation so that it can be proved to be both credible and valid for professional practice (Holloway \& Wheeler, 2002:250). These constructs are used in the establishment of the trustworthiness of the findings.

Credibility is used to prove that the subject of the study is accurately identified and described (De Vos, Strydom, Fouche \& Delport, 2002:351). As a specific setting is studied in qualitative research, the parameters of the setting in this study were defined as the primary health care clinics at state-funded hospitals in the Nelson Mandela Metropole. The findings of the qualitative study will be valid within the parameters of a similar setting. Collation of the findings from each of the participating clinics ensured that all relevant aspects of the subject were analysed (Krefting, 1991:218).

Transferability means that the findings in one context can be transferred to similar situations or participants (Holloway \& Wheeler, 2002:255). The findings in this particular context could be expected to apply to another context such as other diabetic clinics located at other public hospitals.

Prior assumptions should not influence the findings of the qualitative research process. Confirmability allows the reader to trace the details of the research along an audit trail arriving at similar findings to the researcher (Holloway \& Wheeler, 2002:255). Documentation from at least two sources is included in the report, supporting the analysis and interpretation of findings in the final report (Krefting, 1991:221).
Coding was carried out by an independent coder as well as by the researcher. Auditing by the supervisor and co-supervisor ensured that the research plan was checked repeatedly.

\section{Ethical Considerations}

Ethical issues are always an important consideration in any type of research as they are intended to protect participants from any harm, emotional or physical, befalling them during the course of the research study. In any study, the participants should be protected by the preservation of confidentiality, anonymity and safety (Parse, 2001:19).

All information regarding the aims of the study, procedures to be followed during the investigation, as well as the possible advantages of the study and participation were made known to the participants. They were also informed of the reasons for their selection, the duration of the study and how the results will be used and published. They were given the opportunity to consent or decline to take part in the study.

\section{DISCUSSION OF RESULTS}

A central theme was identified as follows:

Registered nurses employed in the Outpatient Departments at state-funded hospitals in the Nelson Mandela Metropole have an overwhelmingly positive view of the South African national guidelines for control and management of DM. They regard the guidelines as a valuable method of ensuring that diabetic patients attending their clinics receive optimal care if implemented correctly. The registered nurses who took part in the study appear to have empathy with their diabetic patients and take great pride in the standard of care they offer their patients. However, the registered nurses expressed frustration and helplessness at the fact that several factors hindered them from implementing the guidelines at an optimal level. The factors hindering the effective implementation of the guidelines were lack of availability of the guidelines, lack of material and human resources, lack of in-service training on utilisation and implementation of the guidelines and lack of opportunity for feedback on the content of the guidelines. 
The themes and sub-themes, identified as forming part of this central theme, are described as follows:

Theme 1: Registered nurses had definite positive views on the national guidelines for Diabetes Mellitus

Sub-theme 1.1 Registered nurses are satisfied with the content of the national guidelines for the management of Diabetes Mellitus

The national guidelines describe the method of diagnosing DM at the initial visit together with clinical signs and symptoms as well as methods of biomedical diagnosis. Non-drug management is given on a stepby-step basis. The emphasis is on self-care and selfmonitoring. Patient education and empowerment is regarded as the most important factor in the management process.

Participants viewed the following as positive:

- Pharmacological management is given in detail with instructions of what should be done if DM remains uncontrolled.

- Both oral anti-diabetic agents and the different types of insulin are dealt with in detail.

- Algorithms for treatment are given as annexures to the guidelines.

- Time intervals for monitoring activities are given (Department of Health, 2004:6).

Carrying out these monitoring activities at allotted time intervals will improve the control of symptoms and will detect the onset of complications at an early stage, when further control measures can be undertaken to limit the possible damage caused by the complications.

The majority of the registered nurses who participated in this study expressed satisfaction with the content of the national guidelines for the management of diabetes mellitus. In fact, the majority of participants appeared excited at the detail of the content of the guidelines. Those who are not specialist diabetic nurses viewed the detailed step-by-step instructions for particular scenarios and the patient education contained in the annexures as most helpful and informative. This is expressed in the following quotations: "It's so complete, everything is there that you want to know about, it really is excellent" and "They will be valuable, especially for one who is not so up to date with diabetic care".

Sub-theme 1.2 Registered nurses view the national guidelines as an effective contribution to the management of Diabetes Mellitus if utilised optimally

All aspects of treatment of DM are addressed in the national guidelines for the management of DM and participants felt that use of the guidelines should lead to a higher standard of care if utilised optimally. The participants felt that the guidelines were extremely useful as a learning tool, giving them more insight into the condition and educating them on how to deal with the diabetic patients in their care, as expressed in the following quotation: "I've gained most ... information which I can utilise for myself and to help my community".

The guidelines are also regarded as a useful tool ensuring standardisation of care in the management of patients with DM. Implementation of the national guidelines aid the standardisation of care of patients with DM if used together with systems such as registries and reminder systems (TRIAD Study Group, 2002:386). A participant expressed the importance of implementation in the following quotation: "It's useless them being on paper and not being implemented, that's the only thing, that's the major thing, because they should be implemented".

Theme 2: Factors hindering the effective implementation of national guidelines for the management of Diabetes Mellitus

Lack and/or inadequate supply of material and human resources are among the factors identified by registered nurses as a major cause of frustration as these hinder them from implementing the national guidelines for the management of DM optimally. These factors are a major cause of feelings of frustration and helplessness as all participants expressed genuine concern and empathy for their patients, wishing to give them all the support and care they are able to give. This frustration was expressed in the following quotation: "I really love diabetics, but it's just so sad, you know, it's frustrating ... if you think you wish you could do more for this patient but you cannot, your hands are tied". 


\section{Sub-theme 2.1 Lack of availability of the guidelines}

The national guidelines for the management of diabetes mellitus were reported by the participants as not being readily available to all health care personnel at the outpatient departments in the hospitals surveyed. When asked by the researcher "Did you know that they existed before I gave you that copy?" a participant stated "No, sister".

\section{Sub-theme 2.2 Lack of material and human resources}

Nursing personnel experience a lack of and/or inadequate supply of material and human resources hindering them from implementing the national guidelines for the management of diabetes mellitus, which is a major source of frustration for the participants.

Lack of resources affects all aspects of the treatment offered to the patients attending the diabetic clinics and the participants feel that they are unable to implement the national guidelines effectively in managing the diabetic patients they treat on a daily basis. Most participants were sceptical about the feasibility of implementing the guidelines in their departments, simply due to a lack of resources such as medication and equipment, for example glucometers, blood lancets and test strips. A participant expressed this in the following statement: "On paper, it sounds wonderful. But if it's going to work in the practical aspect, I don't know. It's a good guideline, if you can go straight according to it but I don't know, we must see".

A factor adding to the frustration experienced by the participants is that they hear of facilities available in other provinces and do not understand why similar facilities are not available to them. There is a perception amongst the participants that staff members at primary health care facilities in other provinces have more access to resources than they have in the Eastern Cape. A participant stated "It's just sad if you think that you can do more for the patients but we are not allowed to do it here. But if you listen to people working in the government sector, say in Gauteng or Western Cape, then they are totally different there, they've got more towards the patients".

Human resources are another issue causing concern and frustration amongst the participants. They are aware of the importance of patient education but the sheer volume of the patients requiring care often makes it difficult for the staff to give each patient the attention they require. This is expressed in the following quotation: "I make the point that they read the pamphlets because we are only three now on duty and we do not have the time to educate the patients, but it must be an ongoing process".

Unfortunately, some of the patients are illiterate or barely literate and do not always understand the instructions given, making the basic principle of self-care and selfmonitoring very difficult to achieve (Department of Health, 2004:4). A participant expressed this as follows: "Some of them have a little bit of a problem understanding it, I am sorry to say that some of those ones have not much education, they have a little bit of a problem, even if we explain".

At some of the hospitals, there is little backup available from medical staff for the registered nurses working in the diabetic clinics, as there are not enough doctors available in the service. The Eastern Cape has the greatest shortage of both nurses and doctors according to the Treasury figures for February 2003, as quoted by Cullinan (2004). The doctor:patient ratio in the Eastern Cape is $1: 8825$ compared to a national average of $1: 3928$. One way in which this affects the diabetic patients is the delay in referrals to specialised clinics where early detection and prevention of complications should be achieved. A shortage of nursing staff also affects the level of service offered and is another cause of frustration amongst the participants. The registered nurse:patient ratio in the Eastern Cape is $1: 1278$ whereas the national average is $1: 916$ (Cullinan, 2004). A participant expressed her concern in the following quotation: "We are actually running a diabetic clinic without a doctor ... you must make decisions sometimes on your own".

\section{Sub-theme 2.3 Lack of adequate in-serv- ice training on utilisation and implementa- tion of the guidelines}

Nursing personnel experience a lack of adequate inservice training concerning the national guidelines for the management of DM, which, if available, would enhance their professional development and service delivery to the diabetic patient. The knowledge of practitioners in the field is sometimes erratic in focus 
with more knowledge in some areas than in others. One participant expressed this concern in the following quotation: "We were just given the guidelines to come and read and implement whatever is there".

Patient education is a cornerstone of the management of patients with DM. Self-management is the basis for management and control of the condition, which means that careful education must be given to the diabetic patient, particularly when newly-diagnosed, to prevent complications.

As patients often have difficulty in complying with the management protocols for DM because of misunderstanding instructions or because of denial of their condition, they make mistakes affecting their glycaemic control. It is important for staff dealing with these patients to be able to identify difficulties experienced by the patients and to deal with them, as Sanders (1998:865) said: "Teachers must be trained to manage patients' mistakes". This is only possible with ongoing in-service training on principles for the management of DM. This is expressed in the following statement by a participant "Train more people about the guidelines, expose more people to the in-service education programmes, send more people to the congresses where there is new updates on new treatments and on new methods of managing diabetes".

Participants indicated that they feel that courses in the management of diabetes are available in the private sector, but no training for staff dealing specifically with in-depth diabetes management seems to be available in the public sector. This is expressed in the following quotations: "It's the private sector, it's the private reps that's arranging it. There's no training coming from the government sector" and "She took me with her to outside lectures and things like that but you never get any inside training".

However, some participants felt that they do not need further training in the treatment of the management of DM. These participants expressed a great deal of pride in the service they offer their patients. Another source of pride is the fact that sometimes doctors in private practice in the Nelson Mandela Metropole refer patients to their diabetic clinic if the patients are experiencing difficulties in management and in achieving glycaemic control. This is expressed in the following quotation: "I think we are pretty clued up here, all of us. Some of the private doctors send their patients here, to the diabetic clinic. They say they can't get them controlled and within three months, these patients are controlled".

Cultural factors regarding diet mentioned in the national guidelines for the management of DM (Department of Health, 2004:4) are important in a multi-cultural and diverse country such as South Africa. Concern was expressed in the following quotation: "Because of our cultural background we eat different things". Some examples of cultural and dietary factors, which may be addressed in in-service education programmes, are the problems experienced by Moslem patients fasting during Ramadan and also vegetarianism that is advocated by some religions (Omar, Motala \& Pirie, 1999:442). The participants in the study felt that they required more inservice education on relevant cultural and dietary factors so that they could improve their service delivery. This has added ramifications as the financial status of the patient has to be taken into account together with the cultural and religious aspects in advising the patient about the correct diet to follow. As rural patients are also seen at the primary health care clinics, one participant said: "There is a small difference between a urban person and a rural person, they need to adjust themselves accordingly".

In the literature survey carried out it was noted that in order for patient education programmes introduced for some communities in other multi-cultural countries, such as the USA, to be effective, it was essential for the nurses taking part to be educated on culturally sensitive teaching methods, allowing them to achieve the required goals of optimal patient care (Philis-Tsimikas, Walker, Rivard, Talavera, Reimann, Salmon \& Auaujo, 2004:112). The importance of making patient education accessible to all was shown in a study undertaken in the public health care sector in Johannesburg which demonstrated the effect of inadequate patient education on the management of DM. Lack of improvement in glycaemic control was attributed to several factors including language barriers causing poor self-monitoring and compliance in these patients (Oldjohn, Osler \& Kalk, 1999:450). These problems were addressed by, amongst other methods, training nurses fluent in black languages as diabetic educators.

Most of the participants in this study expressed a need 
for ongoing in-service education regarding the requirements of the national guidelines for DM. Research conducted in the field of diabetes mellitus is an ongoing process leading to new ideas and methods of managing the condition. This information could be used to improve the service to the patients attending these hospitals. Patient education and empowerment is imperative for optimal management of DM so an ongoing in-service education programme giving the registered nurse the opportunity of increasing her knowledge for the benefit of the patient is of utmost importance (Department of Health, 2004:4).

\section{Sub-theme 2.4 Lack of opportunity for feedback on content of guidelines}

In order to improve continuity of care in the management of DM, feedback is essential for improving all aspects of care of patients with the condition. In a study by Renders et al. (2001:1823), improvement in diabetic care was achieved when adequate feedback of meetings, post graduate education and methods of patient education was given to registered nurses. Feedback is also a valuable tool allowing reflection on the effectiveness of the implementation of the guidelines in practise (Mohamed, 2001:46).

Some of the participants in this study feel that opportunities are not created for nursing personnel to provide feedback on various aspects of the national guidelines for the management of DM so that suggestions or uncertainties can be addressed. This is expressed in the following quotation: "We never get a chance to do that, it will be nice to be able to do it, you know, but we don't get there". The specialist diabetic nurses who took part in the research are satisfied with the opportunities they have to undergo training, attend committee meetings and congresses. One of the specialist diabetic nurses stated: "I go to all the committee meetings and so on and all the meetings they have in the Metropole for diabetics, I go to. What I hear there, I bring back so they stay up to date". However, other participants are not always satisfied as they feel that the opportunities for other nursing staff to attend the meetings and training sessions are limited. One participant stated: "She will come back and give us feedback, but we are not always there for the first time on hand experience".

As it is not possible for all nursing staff in a department to attend a particular meeting, conference or training session, it is essential for those unable to attend to receive feedback on the meetings. Important decisions may be taken at a meeting or training session about, for example, procedures to be implemented or methods of carrying out tasks. It is imperative for the staff to receive feedback on these decisions in order for optimal service delivery to be achieved. Participants expressed their frustration in the following quotations: "She's not very keen to teach the other nurses. As a result the other nurses do not know much about Diabetes Mellitus and the guidelines and the implementation of the guidelines" and "What do you think if the next person will take over, what is going to happen then?" Feedback sessions allow any queries or uncertainties to be dealt with before problems arise. This is an important method of reducing frustration in the work place, as staff will feel that they play a greater role in service delivery.

\section{RECOMMENDATIONS TO ASSIST REGISTERED NURSES IN THE OPTIMAL IMPLEMENTATION AND UTILISATION OF THE NATIONAL GUIDELINES FOR THE MANAGEMENT OF DIABETES MELLITUS}

The recommendations based on the findings of this study are designed to assist the registered nurse in the optimal implementation and utilisation of the national guidelines for the management of DM. The researcher faced a major challenge in making appropriate and realistic recommendations mainly due to the lack of financial resources available for the provision of primary health care in the Eastern Cape. Guidelines for the control and management of patients with various conditions, including DM, are compiled by the national Department of Health. However, in practice it is often extremely difficult to comply with the provisions of the guidelines because of various factors such as those identified in this study. A schematic representation of the recommendations made is given in Table 1.

\section{Ensure availability of the guidelines}

A great deal of research and planning is put into the development of the national guidelines for the management of DM. Unfortunately, it appears that there is a breakdown in the process of distribution as the participants in this study were not aware of the existence of the guidelines. 
It is recommended that copies are made available in all examination rooms in Outpatients Departments of the hospitals concerned. Provincial representatives of the Department of Health can be approached to obtain copies of the guidelines. Summaries of the guidelines and algorithms of treatment may be made in poster format and placed in the examination rooms.

\section{Improve access to material and human resources}

Basic equipment such as glucometers, sphygmomanometers, thermometers, stethoscopes and ophtalmoscopes should be available in each clinic.

Table 1: Recommendations to enable the optimal implementation and utilisation of the national guidelines for the management of DM

\begin{tabular}{|c|c|}
\hline RECOMMENDATIONS & METHODS OF IMPLEMENTATION \\
\hline $\begin{array}{l}\text { Ensure availability of } \\
\text { guidelines }\end{array}$ & $\begin{array}{l}\text { - } \\
\text { reproach provincial Department of Health } \\
\text { guidelines for the management of DM. } \\
\text { Ensure that copies of guidelines are available in all } \\
\text { examination rooms in Outpatients Departments. } \\
\text { Make summaries of guidelines and algorithms of } \\
\text { treatment available in poster format in the } \\
\text { examination rooms. }\end{array}$ \\
\hline $\begin{array}{l}\text { Improve access to material } \\
\text { and human resources }\end{array}$ & 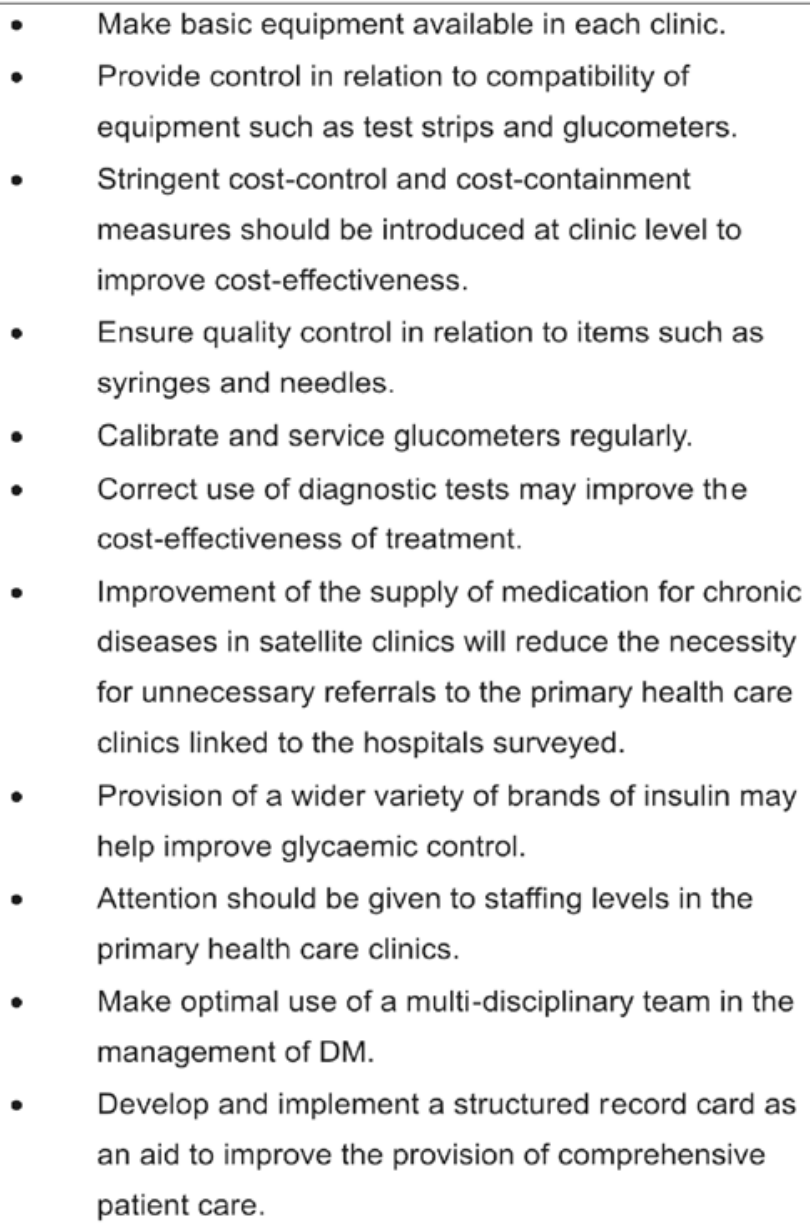 \\
\hline
\end{tabular}




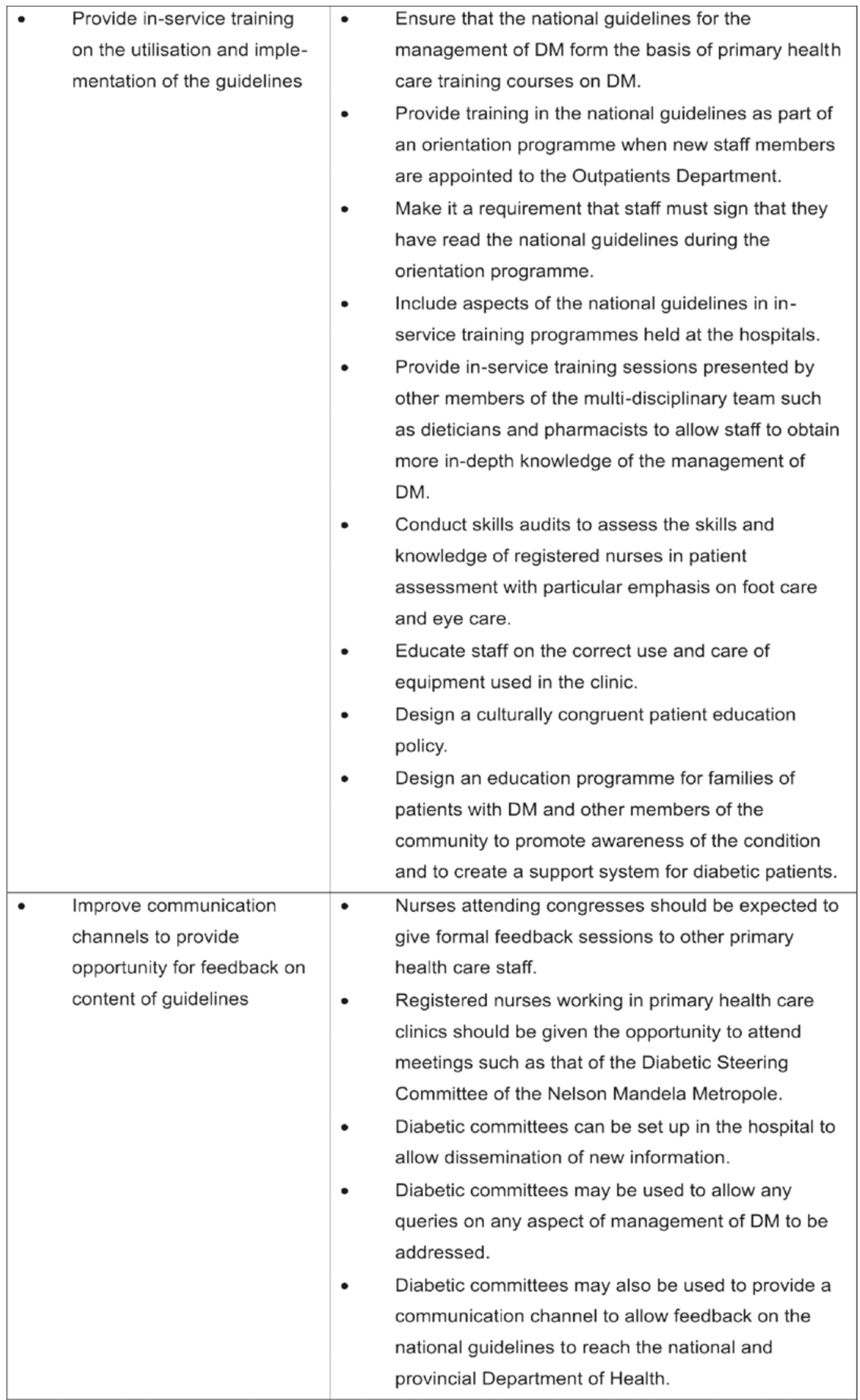


Stringent cost-control measurements should be undertaken. At the same time, attention should be given to the tendering system to ensure that good quality supplies are made available in the most cost-effective manner possible.

Quality control on supplies such as syringes and needles should be carried out and all equipment should be compatible with each other for example, the test strips and glucometers. Regular servicing of equipment will improve their life span.

Correct diagnostic tests should be made available at the clinics to improve cost-effective treatment and assist in the earliest possible detection of complications. A wider variety of brands of insulin should be available to improve glycaemic control as not all patients find the limited range of available insulins compatible with them.

Staffing levels should be adequate for the number of patients seen to improve service standards and to prevent burn-out in the staff. Different ways of dealing with the patient flow can be used to improve patient turnover. Optimal use of the multi-disciplinary team can encourage patient compliance and lead to earlier detection and prevention of complications.

A structured record card can aid the provision of comprehensive patient care by acting as a prompt for performing diagnostic tests at correct intervals and as an aid in patient counselling.

\section{Provide in-service training on the guidelines for the management of Diabetus Mellitus}

The inclusion of a policy of self-management was found to be basic to national guidelines in several countries around the world, in a comparative analysis undertaken by Burgers, Baily, Klazinga, Van der Bij, Grol and Feder (2002:1936). Such a policy requires intensive patient education on all aspects of the condition. In order to provide adequate patient education, the registered nurse must be trained in all areas of DM.

Training on the national guidelines should be part of any orientation programme for new staff appointed to the Outpatients Department. All staff should sign that they have read the guidelines. Aspects of the national guidelines should form part of an in-service training programme at each hospital and other disciplines should also be included.

Skills audits to assess the skills of the nursing staff should be carried out. Staff should also be educated on the correct use of equipment especially when new models are purchased.

A culturally congruent patient education policy should be designed as well as an education programme for families of patients with DM and other members of the community. This could form the basis of a support group for the patients.

\section{Improve communication channels to provide opportunity for feedback on the content of the guidelines}

Nurses attending congresses must be expected to give formal feedback sessions to other primary health care staff. Registered nurses working in primary health care clinics should be given the opportunity to attend meetings such as that of the Port Elizabeth Diabetic Steering Committee.

Diabetic committees could be set up in hospitals to allow dissemination of new information, allow any queries on management of DM to be addressed and to provide a communication channel about the national guidelines to be routed to the correct liaison persons in the national and provincial Departments of Health.

\section{LIMITATIONS OF THE STUDY}

- A limitation in this study was the fact that only registered nurses working in the hospital Outpatient Departments were interviewed. Further input from registered nurses working in the satellite primary health care clinics may be of value.

- Another limitation of this study is the fact that there is no input from registered nurses employed in the private sector.

\section{RECOMMENDATIONS FOR NURSING PRACTICE, NURSING EDUCATION AND NURSING RESEARCH}

Several recommendations can be made to enable the 
findings of this research study to be implemented in nursing practice, education and research.

The guidelines should be made available in all the examination rooms of the Outpatient Departments at the hospitals in the Nelson Mandela Metropole and should also be included in the in-service education programmes of those hospitals. More opportunities to provide feedback from meetings and training session on all aspects of DM management should be provided on a regular basis, allowing staff to be given the opportunity to raise any queries they may have.

Workshops and courses on the management of DM should be developed and all registered nurses given the opportunity to attend. Opportunities for feedback and communication between staff members must be allowed so that information obtained at workshops and courses may be disseminated amongst all nursing staff and any queries raised may be dealt with. Nurses must be educated on cultural aspects of diet and lifestyle management to make patient education relevant to the particular population group being educated.

Similar studies may be conducted with registered nurses from the outlying primary health care clinics in the Nelson Mandela Metropole and also with those working in the private sector as participants. A followup study could ascertain if the implementation of the national guidelines leads to an improvement in glycaemic control in the clinics at the hospitals of the Port Elizabeth Hospital Complex. A study of the economic consequences of complications of DM in the Eastern Cape may emphasise the value and cost-effectiveness of preventive management of DM. A study to assess the relevance of the curriculum for nursing training in both basic and post-basic programmes, for example primary health care courses, may assist in the provision of improved education programmes. A study on the cultural aspects of DM regarding issues such as fasting may improve the provision of culturally sensitive patient education to patients of other cultures. An exploration of the needs of the diabetic patients in the field of patient education may assist in improving the value of patient education programmes.

\section{CONCLUSION}

Diabetes Mellitus is a chronic lifestyle disease with far reaching implications, both for the patients suffering from the condition and for the health services in countries around the world. Evidence-based guidelines have been created to optimise treatment by enabling early identification of the disease in patients, create a framework for patient education and prevent complications by identifying treatment modalities.

In this study, the views of the registered nurses working in primary health care clinics at hospitals in the Nelson Mandela Metropole on the national guidelines for the management of DM have been explored and described. The participants in the survey all expressed definite positive views of the guidelines and were satisfied with the content of the guidelines. They also viewed the guidelines as a positive contribution to optimal management of DM, if implemented correctly. Several factors hindering the implementation of the national guidelines were identified. Recommendations to assist the registered nurse in the implementation and utilisation of the guidelines were constructed. The registered nurses who took part in this survey all expressed a deep empathy and concern for their patients. The participants expressed pride in the quality of care, which they offer their patients, in spite of the limitations and hindrances experienced each day.

\section{REFERENCES}

AMERICAN DIABETES ASSOCIATION 2002: Standards of medical care for patients with diabetes mellitus (Position statement). Diabetes Care, 25(i):213-230

BANTUBANI, N; PUOANE, T \& LEVITT, NS 2003: Situational analysis of management of diabetes in the Umzimvubu Area, Alfred Ndzo District, Eastern Cape. Journal of Endocrinology, Metabolism and Diabetes of South Africa, 8(1):37.

BURGERS, JS; BAILEY, JV; KLAZINGA, NS; VAN DER BIJ, AK; GROL, R \& FEDER, G 2000: Inside guidelines - A comparitive analysis of recommendations and evidence in diabetes guidelines from 13 countries. Diabetes Care, 304:1215-1218.

BURNS, N \& GROVE, SK 2003: Understanding nursing research. Philadelphia: Saunders.

CRESWELL, JW 2003: Research Design: Qualitative, quantitative and mixed methods approaches; $2^{\text {nd }}$ edition. Thousand Oaks: Sage. CULLINAN, K 2004: Eastern Cape - Health care crisis. http://healthe.org.za/news/article.php/uid=20030978 (Accessed: 02 January 2005).

DE VOS, AS; STRYDOM, H; FOUCHE, CB \& DELPORT, CSL 2002: Research at grass roots; $2^{\text {nd }}$ edition. Pretoria: Van Schaik. 
DEPARTMENT OF HEALTH 2004: National programme for control and management of diabetes type 2 at primary level. (Revised). Cape Town: South African Communication Service.

DRAFT ENVIRONMENTAL IMPACT REPORT 2002: Proposed Aluminium Pechiney Smelter Within The Coega Idz Chapter 4: Description of the affected environment. http://smelter.csir.co.za/ eia_draft_chapter_4.pdf. Pg 4-1-4-19 CSIR. (Accessed: 26 April 2004).

HOLLOWAY, I \& WHEELER, S 2002: Qualitative research in nursing; $2^{\text {nd }}$ edition. Oxford: Blackwell.

KREFTING, L 1991: Rigor in qualitative research: The assessment of trustworthiness. American Journal of Occupational Therapy, 45(3):214-222.

LARME, AC \& PUGH, JA 2001: Evidence-based guidelines meet the real world. Diabetes Care, 24(10):1728-1733.

LEUNER, S 2000: Diabetes Care in South Africa. Specialist Medicine, $\mathrm{XXII}(7): 410-415$.

MOHAMED, ES 2001: The awareness and knowledge of the PHC clinicians in Soweto about the national diabetes type 2 guidelines and their attitude towards it. Johannesburg: University of Witwatersrand (Unpublished MPH dissertation).

MULLER, M 1998: Nursing dynamics; $2^{\text {nd }}$ edition. Johannesburg: Heinemann.

OLDJOHN, A; OSLER, C \& KALK, WJ 1999: Standards of diabetic care - Successes and failures of a patient education policy. South African Medical Journal, 89(4):445-451.

OMAR, MAK; MOTALA, A\& PIRIE, F 1999: The Ramadan fast and the diabetic patient. South African Medical Journal, 89(4):441445.

PARSE, RR 2001: Qualitative inquiry: The path of sciencing. Sudbury: Jones \& Bartlett.

PHILIS-TSIMIKAS, A; WALKER, C; RIVARD, L; TALAVERA, G; REIMANN, JOF; SALMON, M \& AUAUJO, R 2004: Improvement in diabetes care of underinsured patients enrolled in Project Dulce. Diabetes Care, 27(1):110-113.

RENDERS, CM; VALK, GD; GRIFFIN, SJ; WAGNER, EH; VAN, JTE \& ASSENDELFT, WJJ 2001: Interventions to improve the management of diabetes in primary care, outpatient and community settings. Diabetes Care, 24(10):1821-1833

ROTCHFORD, AP \& ROTCHFORD, KM 2002: Diabetes in rural South Africa - An assessment of care and complications. Journal of Endocrinology, Metabolism and Diabetes of South Africa, $7(2): 60-65$.

SAFRAN, MA; MUKHTAR, Q \& MURPHY, DL 2003: Implementing program evaluation and accountability for population health: progress of a national diabetes control effort. Journal of Public Health Management and Practice, 7(1):58-66.

SANDERS, FN 1998: How to improve compliance in diabetic patients. Continuing Medical Education, 16(9):864-866
SMELTZER, SC \& BARE, BG 2004: Brunner and Suddarth's Textbook of medical-surgical nursing; $10^{\text {th }}$ edition. Philadelphia: Lippincott. TRIAD STUDY GROUP 2002: The translating research into action for diabetes (TRIAD) study. Diabetes Care, 25(2):386-389 WILKINSON, D; GOUWS, E; SACH, M \& KARIM, SS 2001: Effect of removing user fees on attendance for curative and preventive primary health care services in rural South Africa. Bulletin of the World Health Organization, 79(7):665-71. 